\title{
Reform Communism and Neo-Marxism in West Bengal: A Theoretical-Explorative Design
}

\author{
Md. Ayub Mallick, \\ Faculty, Department of Political Science, University of Kalyani, Kalyani, Nadia
}

\begin{abstract}
The political and administrative power of the Indian state is bounded by structural constraints based on democratic legitimization. It can be explained by the Althussarian-Poulantzasian tradition of structuralism vis-à-vis instrumentalism. The Left Front has had to function within a given structure and a system where the state structure and economic system are in the service of the vested interests, and the constitution, laws, institutions, management and administration for higher ups and against the masses. Secondly, within such structures the Left Front has had very limited powers to use and transform society accordingly. In fact, structural dependence exists in a dynamic and progressive sense. Government can manage workers through redistributive policies and reformist programmes within the periphery of the democratic capitalist society. In fact, the leftist leaders used 'class' as a currency to buy votes, which had nothing to do with lower-class emancipation. Since coming to power the left forces began to consolidate its rural power position by organizing and institutionalizing the peasantry and labourers, and also by politicizing the panchayats.
\end{abstract}

Key words: Reform communism. Neo-Marxism. Marxism-Leninism. Structural constraints. Hegemony. Economism. Rural Power Structure.

The election highlighted the central role of group identifications, not individual citizenship, as the basis of democratic practice. The open and competitive use of deadly violence - a remarkably literal reflection of Michel Foucault's famous formula (inverting Clausewitz) that 'politics is the continuation of war by other means' reflected what the election was really about: relations of power in the village (Foucault 2003:15). This explains both the lack of ideological debates or policy platforms and the intensity of contestation. Despite a lack of policy 'substance', this election was desperately meaningful for most people. I would suggest, therefore, that to evaluate this election in terms of its legitimacy as a valid expression of 'democracy' would miss the point: 'the pertinent opposition is not between the legitimate and the illegitimate, but that between struggle and submission' (Foucault 2003:17). The struggle is for power and submission to power.

This leads Chatterjee (2004: 36-37) to describe postcolonial democracy as a 'politics of the governed', contrasting what he calls 'political society' with an elite-inhabited 'civil society' composed of the formal legalconstitutional structure of which every citizen is in theory a member but that he argues is quite different from the realities of political life in postcolonial contexts. That is, if 'civil society' refers to the abstract ideals of liberal citizenship, in practice the heterogeneity of "political society" is where the rough and tumble of everyday politics gets done. Chatterjee focuses on the ways in which 'political society' operates in the interstices of governmentality, with subaltern groups manipulating governmental practices and categorizations, often in disregard of the formal legal system, to gain access to development resources and secure their often-precarious positions.

In essence, the main efforts are directed to the arena of parliamentary politics and non-violent extraparliamentary activities for 'achieving power in Indian politics rather than attempt to fit national strategy to international strategy and then to drive specific tactics from the grand design to fit the Indian situation.' (Brass, 1973: 68). Deeply embedded in electoral politics for winning elections to sit on a power-saddle, but not simply 'a camouflage or part time activity designed to conceal more sinister conspiratorial games' (Field and Franda, 1974: 3), the left parties are involved in creating a mirage of revolution, an extreme feasibility of MarxismLeninism. It is nothing but replacing the reality of class struggle by the slogans of class struggle and by the practice of class collaboration and secondly, the task of replacing proletarian socialism by bourgeois socialism. It is betrayal to Marxism-Leninism (Retzlaff, 1965). The 'workability' (Dattagupta, n.d.: 31) of the Left Front is totally deviated from Marxism-Leninism, from its tasks 'of weakening bourgeois rule' (Dattagupta, n.d.: 32) and thereby weakens the 'autonomous political space' (Dattagupta, n.d.: 32). Conditioned by the structure and institutions of bourgeois regime or to use Nicos Poulantzas's expression 'the organizing matrix behind institutions', the Left Front has not been able to fight for the displacement of bourgeois domination rather than electoral victory and mere reformism.

The political and administrative power of the Indian state is bounded by structural constraints based on democratic legitimization. It can be explained by the Althussarian-Poulantzasian tradition of structuralism vis-à- 
vis instrumentalism. Police administration in India is unofficially essentially politicized. Essentially, 'In parliamentary-democratic political regimes, any political group or party can win control over institutional state power only to the extent that it wins sufficient electoral support in general elections. This mechanism plays a key role in disguising the fact that the material resources of state power, and the ways in which these are used, primarily depend upon the revenues derived from the accumulation process, and not upon the voting preferences of the general electorate... there is a dual determination of the political power of the capitalist state: the institutional form of this state is determined through the rules of democratic and representative government, while the material content of state power is conditioned by the continuous requirements of the accumulation process.' (Offe, 1984: 121). It is like 'passive revolution of capital'. This is the essential aspect of the hegemonic construction of post-colonial state and administration 'combining accumulation with legitimation while avoiding the "unnecessary rigours" of social conflict.' (Chatterjee, 1997: 289). Rational strategies are pursued in political and administrative spheres. For management of conflicts police administration and political mobilization are essential to contain conflicts within manageable limits. To this end, 'passive revolution' is important to retain legitimacy through representative and electoral democracy. It is not surprising that democracy appears so feeble when faced with the power of capital. 'The institutional form of this state is determined through the rules of democratic and representative government, while the material content of state power is conditioned by the continuous requirements of the accumulation process.' (Offe, 1984: 121). 'The presumed sovereignty of the democratic citizenry fails in the presence of capital strike.' (Bowles and Gintis, 1986: 90). The democratic process may bring governments with radically different bases of support into office but not governments with radically different programs. Radical or socialist dream is far away from the realities and activities of the left parties, especially the CPI (M) and Left Front government led by the CPI (M). Combination of few external and internal factors facilitates the cyclic process of reformism. These factors like $E_{1}, E_{2}, E_{3}$ and $E_{4}$, and $I_{1}, I_{2}$ and $I_{3}$ together form an angle of $45^{\circ}$. It is a zigzag process of moving from external factors to internal factors, and then to a distant dream of socialism or radical change far away from the original on-going process of reformism. In fact, both conservatizing and socializing pressures contribute to CPI (M)'s reformism and long-tenure in office (Fig. 1).

Poulantzas's (1973, 1974 and 1975) theory of the state was reacting against what he saw as more simplistic understandings within Marxism. Instrumentalist Marxist accounts held that the state was simply an instrument in the hands of a particular class. Poulantzas disagreed with this, because he saw the capitalist class as too focused on their individual short term profit, rather than on maintaining the class's power as a whole, to simply exercise the whole of state power in its own interest. Poulantzas argued that the state, though relatively autonomous from the capitalist class, nonetheless functions to ensure the smooth operation of capitalist society, and therefore benefits the capitalist class. In particular, he focused on how an inherently divisive system such as capitalism could co-exist with the social stability necessary for it to reproduce itself looking in particular to nationalism as a means to overcome the class divisions within capitalism. Poulantzas has been particularly influential over the leading contemporary Marxist state theorist, Bob Jessop. In so far as Political Power and Social Classes is concerned, Poulantzas pointed to the direction that an analysis of the differences between the fascist State and the parliamentary forms of bourgeois State would have to be taken into consideration. In Fascism and Dictatorship Poulantzas applied this direction of differences and attempted to establish the exceptionality of fascism as exceptional capitalist State. Thereby he rejected Miliband's criticism of superdeterminist structuralism against Poulantzas. Laclau (1975) criticized Althusserian-Poulantzasian conception of 'instances' such as economic, political and ideological, which are both specific and autonomous with respect to each other and whose interaction produces the mode of production, determined by the economic in the last resort and in which another instance may play dominant role. To Poulantzas, 'By mode of production we shall designate not what is generally marked out as the economic (i.e. relations of production in the strict sense), but a specific combination of various structures and practices (economic, political, ideological) which, in combination, appear as so many instances or levels... of this mode.' (Poulantzas, 1973: 13). Borrowing from Antonio Gramsci's notion of cultural hegemony, Poulantzas argued that repressing movements of the oppressed is not the sole function of the state. Rather state power must also obtain the consent of the oppressed. It does this through class alliances, where the dominant group makes an 'alliance' with subordinate groups, as a means to get the consent of the subordinate group. Gramsci regarded that the methods of attaining hegemony in democratic capitalist countries, i.e. subordinating opposing forces and winning active or passive consent of subaltern allies at the same time. In his later works, Poulantzas analyzed the role of what he termed the 'new petty bourgeoisie' in both consolidating the ruling classes' hegemony and undermining the proletariat's ability to organize itself. The role police and army are important in maintaining class power and hegemony. Lastly, it may be mentioned here that -

... the system of the State is composed of several apparatuses or institutions of which certain have a principally repressive role, in the strong sense, and others a principally ideological role. The former constitute the repressive apparatus of the State, that is to say the State apparatus in the 
classical Marxist sense of the term (government, army, police, tribunals and administration). The latter constitute the ideological apparatuses of the State, such as the Church, the political parties, the unions (with the exception of course, of the revolutionary party or trade union organizations), the schools, the mass media (newspapers, radio, television), and, from a certain point of view, the family. This is so whether they are public or private - the distinction having a purely juridical, that is, largely ideological character, which changes nothing fundamental. This position is in a certain sense that of Gramsci himself,... If the State is defined as the instance that maintains the cohesion of a social formation and which reproduces the conditions of production of a social system by maintaining class domination, it is obvious that the institutions in question - the State ideological apparatuses - fill exactly the same function.' (Poulantzas, 1969: 77).

The Left Front has had to function within a given structure and a system where the state structure and economic system are in the service of the vested interests, and the constitution, laws, institutions, management and administration for higher ups and against the masses. Secondly, within such structures the Left Front has had very limited powers to use and transform society accordingly. Therefore, the real problem is structural constraint (CPI-M, West Bengal State Committee, 1982). The solution lies in change - a 'basic structural change' in Central economic policy and 'a national democratic change' (CPI, 1982: 20) in Central power structures by a new left and national democratic power structure in alteration and along the path of antiimperialism, anti-monopoly and anti-feudalism. This can be actualized by means of a unified, militant and longterm mass movement in association with 'political and ideological struggle' (CPI, 1982: 4). To include the masses in this struggle the party prescribes at least three or four ways: one, a huge and large-scale obstructions against waywardness with the help of secular bourgeois opposition parties; two, 'formation of a left and democratic front for a left and democratic unity struggle with the help of all left forces' (CPI-M, 1986: 11), three, a magnificent increase in the activities of the party and its mass organizations devoid of revisionist setback. Four, application of Marxism-Leninism to actual Indian conditions in the interests of workers-peasantslabourers unity, of mass democratic front and mass democratic revolution that correspond to a parliamentary government under a communist leadership (CPI-M, 1988: 45), capable of leading Indian revolution and moulding a centrally organized state instrument of a centrally organized powerful bourgeois-landlord alliance, transforming an embryo consciousness into a 'political and socialist consciousness' (CPI-M, n.d.: 7). The left forces regard to strengthen the parliamentary democratic system and improve the functioning through constant hard labour (CPI-M, 1986). Secondly, it tries to consolidate a unified workers' movement and a consequent ideological struggle, otherwise workers' movement must not come into contact with a wide-scale political consciousness and itself free from 'economism' and political inertia, dissociation between party and mass organization, and 'dissection of mass movements from mass organizations' (CPI-M, 1986: 93). Thirdly, it has to unshackle the economy, to free our society from growing corruption among politicians and bureaucrats and escalated criminalization of politics, but not to be accommodative of group claims and postpone action due to conflicting claims. 'To win the votes of people other than workers, particularly the petty bourgeoisie, to form alliances and coalitions, to administer the government in the interests of workers, a party cannot appear to be "irresponsible", to give any indication of being less than wholehearted about its commitment to the rules and limits of the parliamentary game.' (Przeworski, 1980: 30-31). Przeworski and Wallerstein (1988) regard that the state in a capitalist society is not structurally dependent on capital in a static way, as it is found that a welfare state, sympathetic to the working class and disadvantaged groups is not handicapped in the face of capital. In fact, structural dependence exists in a dynamic and progressive sense. Government can manage workers through redistributive policies and reformist programmes within the periphery of the democratic capitalist society. The state in the wider sense is the combination of state proper and the civil society, i.e. the entire complex of practical and theoretical activities with which the ruling class justifies and maintains its dominance, and even manages the active consent of the subjects (Gramsci, 1971). The function of domination is punctuated by leadership by consent. Pointing on the 'leadership' with a 'hegemonic' fervour Gramsci puts on very eloquently his formula of 'spontaneity and conscious direction', which is applicable to left movement in West Bengal to become a success. He says,

This leadership was not "abstract"; it neither consisted in mechanically repeating scientific or theoretical formulae, nor did it confuse politics, real action, with theoretical disquisition. It applied itself to real men, formed in specific historical relations, with specific feelings, outlooks, fragmentary conceptions of the world, etc., which were the result of "spontaneous" combinations of a given situation of material production with the "fortuitous" agglomeration within it of disparate social elements. This element of "spontaneity" was not neglected and even less despised. It was educated, directed... It gave the masses a "theoretical" consciousness of being creators of historical and institutional values, of being founders of a State. This unity between "spontaneity" and "conscious leadership"... is precisely the real political action of the subaltern classes, in so far 
as this is mass politics and not merely an adventure by groups claiming to represent the masses. (Gramsci, 1971: 198).

Unlike Althusser, Gramsci emphasizes struggle. He noted that 'common sense is not something rigid and immobile, but is continually transforming itself' (Gramsci, cited in Hall 1982: 73). As Fiske puts it, 'Consent must be constantly won and re-won, for people's material social experience constantly reminds them of the disadvantages of subordination and thus poses a threat to the dominant class... Hegemony... posits a constant contradiction between ideology and the social experience of the subordinate that makes this interface into an inevitable site of ideological struggle.' (Fiske, 1992: 291). Poulantzas (1973) regards that the capitalist state has flexibility of conceding the economic interests of the certain dominated classes within the limits of the system and in accordance with the hegemonic domination of the dominant classes as representatives of the general interests of the people. It is a form of power based on consent, which is organised and directed in a specific manner for the dominated classes. "The notion of the general interest of the "people", an ideological notion covering an institutional operation of the capitalist state, expresses a real fact: namely that this state, by its very structure, gives to the economic interests of certain dominated classes guarantees which may even be contrary to the short-term economic interests of the dominant classes, but which are compatible with their political interests and their hegemonic domination.' (Poulantzas, 1973: 190-91). Poulantzas quotes Gramsci (1971: 182) that the 'life of the state is conceived of as a continuous process of formation and superseding of unstable equilibria... between the interests of the fundamental group and those of the subordinate groups - equilibria in which the interests of the dominant group prevail, but only up to a certain point, i.e. stopping short of narrowly corporate interest.' (Op. cit., Poulantzas, 1973: 190). '... the State/government, conceived as an autonomous force, should reflect back its prestige upon the class upon which it is based, is of the greatest practical and theoretical importance, and deserves to be analysed more fully if one wants a more realistic concept of the State itself.' (Gramsci, 1971:. 269). However, Gramsci does not elevate the superstructure to independent status. Rather, he conceives of the superstructure as being dialectically related to the economic base: '... structures and superstructures form an 'historical bloc'. That is to say the complex, contradictory and discordant ensemble of the superstructure is the reflection of the ensemble of the social relations of production. From this, one can conclude: that only a totalitarian system of ideologies gives a rational reflection of the contradiction of the structure...This reasoning is based on the necessary reciprocity between structure and superstructure, a reciprocity which is nothing other than the real dialectical process.' (Gramsci, 1971: 366). Althusser (1971) states: 'It is easy to see that this representation of the structure of every society as an edifice containing a base (infrastructure) on which are erected the two 'floors' of the superstructure, is a metaphor, to be quite precise, a spatial metaphor...this metaphor...suggests that the upper floors could not 'stay up' (in the air) alone, if they did not rest precisely on their base... Thus the object of the metaphor of the edifice is to represent above all the 'determination in the last instance' by the economic base.' (Althusser, 1971: 135).

The left forces had pursued a strategy of class reconciliation to encourage rural entrepreneurship. Left did not regard rich peasants as 'jotedars', who were essentially the class enemies. Rich peasants were class allies to them in their struggle against landlordism. They were in favour of multi-class alliance of share-croppers, marginal and small peasants, fishermen, artisans and crafts-persons and unified krishak movement. CPI (M) leader, Promode Dasgupta said, 'We do not regard the big farmer as a representative of feudal monopoly interests. Our class struggle is against landed jotedars, not against the big farmer.' (Op. cit., Sen Gupta, 1981: 99). Left politics headed by CPI (M) has abandoned class discourses and adopted a non-class, diffused and general discourses of national integration, mobilization, participation and development that must incorporate the demands and aspirations of every strata or largest cross-section of the society that are affected by the state policies. Development of productive forces is essential to reach the level of revolutionary upsurge. 'No socialist revolution will succeed until "capitalist production has already developed the productive forces of labor in general to a sufficiently high level." Premature attempts at revolution, whatever their immediate outcome, will eventuate in a restoration of capitalist society.' (Cohen, 1978: 206). Retreated from class politics it is the hegemonised politics that rules the left politics in West Bengal. The non-hegemonic left rule has declined in West Bengal. Javed Alam (1991) regards that the 'non-hegemonic conquest' model is the main factor for the failure of communist movement in India and same is the case with the CPI (M) and Left movement in West Bengal. The ability to assess the situation, movement and the political space and to take proper tactical approach is the precondition of hegemonic politics of a political party. 'The concept of hegemony is not simply a cultural concept but evolves all arena of political activity. Whenever a party fails to properly assess the situation and accordingly utilise all opportunities of extending its political-ideological hegemony, the "inevitable" result is the "paradoxical propensity" among the people who look towards that party for leadership. In other words, we would suggest, social and political spaces do not lie vacant, ever. The inability to fill them up, that is, not to fight battles will create the scope for others to walk in and fill in those spaces.' (Nigam, 1996: 905).

Hegemony or domination is associated with exploitation. Eric Olin Wright regards that exploitation is intimately linked to the problem of domination, that is, the social relations within which one person's activities 
are directed and controlled by another. Domination occurs in the exclusion principle, that is, "owning" a resource gives one power to prevent other people from using it. The power exercised by employers to hire and fire workers is the clearest example of this form of domination. But domination also occurs, in most instances, in conjunction with the appropriation principle. The appropriation of the labour effort of the exploited usually requires direct forms of subordination, especially within the labour process, in the form of bossing, surveillance, threats, etc. Exploitation coupled with domination defines the central features of the structured interactions within class relations. In Weberian class analysis, just as much as in Marxist class analysis, the rights and powers individuals have over productive assets defines the material basis of class relations. Control over resources affects bargaining capacity within processes of exchange and this in turn affects the results of such exchanges, especially income. Class is itself directly identified within inequalities in income, since both begin with the problem of the social relations that determine the access of people to economic resources. In a sense, therefore, Marxist and Weberian definitions of class relations in capitalist society share the same basic operational criteria. The Marxist model sees two causal paths, are being systematically generated by these relations - one operating through market exchanges and the other through the process of production itself whereas the Weberian model traces only one causal path. Marxist model elaborates the mechanisms of these causal paths in terms of exploitation and domination as well as bargaining capacity within exchange, whereas the Weberian model only deals with the bargaining within exchange. In a sense, then, the Weberian strategy of class analysis is nested within the Marxist model (Wright, 1985). Wright essentially disregards Marxian class polarization. '... radical polarization of class relations within the capitalist societies is incorrect... Among wageearners, the growth of professional and technical occupations and the expansion of managerial hierarchies in large corporations and the state have at least created the appearance of a considerable erosion of a simple polarized structure.' (Wright, 1985: 8-9). Wright investigates the influence of class structure on class consciousness. Przeworski denies that class structure is prior to class formation and class struggle. In Przeworski's (1977) words, 'Classes must thus be viewed as effects of struggles structured by objective conditions that are simultaneously economic, political, and ideological. ... Precisely because class formation is an effect of struggles, outcomes of this process are at each moment of history to some extent indeterminate.' (Przeworski, 1977: 343). The left forces in West Bengal theoretically believe these patterns of dominationsubjugation relationships. But this type of domination is not purely economic, but at the same time ideological and political. Actually, the left forces pursue class collaboration rather than class struggle between the 'haves' and 'have-nots'. 'Exploitation, rather, should be conceived of as an injustice in the distribution of income resulting from a distribution of endowments which is unjust.' It is like Roemer's 'rational choice' Marxism. (Roemer, 1985: 1441). The labourers had to suffer from 'class-for-itself' and Bengal Unit of All India Kisan Sabha did not rise above mere 'economism'. They had to suffer from low level of class consciousness and organized agrarian movement. 'The minimum wage levels fixed by the government have helped to define a target, and to strengthen the case of the labourers in their bargaining with the landowners. But the outcome of such bargains has been determined by the factors like the aggregate level of demand for labour, the strength of the organization of agricultural labourers, and the extent of intervention by the panchayat through its public works programme in the labour market.' (Dasgupta, 1984: A-146).

'The central and only distinctive claim of Marxist political theory is that under capitalism all governments must respect and protect the essential claims of those who own the productive wealth of society. Capitalists are endowed with public power, power that no formal institutions can overcome. People may have political rights, they may vote, and governments may pursue popular mandates. State managers may have interests and conceptions of their own. But the effective capacity of all governments to attain whatever goals is circumscribed by the public owner of capital. The nature of political forces that control the state institutions does not alter this situation, for it is structural: a characteristic of the system, not of occupants of governmental positions or the winners of elections.' (Przeworski, 1990: 65). Przeworski's strategic conception of the state is similar to that of Jon Elster (1985). Elster uses Prisoner's Dilemma model to explain the class situation. Common class interests exist in capitalist society, but there is a strong tendency to seek individual advantage by defecting from co-operative class strategy. 'The task of the state is to provide a co-operative solution for the Prisoner's Dilemma faced by members of the economically dominant class, and, as part of this task, to prevent the members of the dominated class from solving their dilemma.' (Elster, 1985: 400). The left forces in West Bengal were not able to change the rural power structure and connected with the rural power structure, where the 'jotedars', the affluent farmers had to give economic assistance to the rural poor in terms of loan for consumption; the 'power structure' tended to maintain the status quo through the conditions of scarcity, richpoor disparity and indebtedness without making an agricultural breakthrough; there was no free competition among the labourers for work and employers for cheapest labour and profit (Gupta, 1972). The lower castes and disadvantaged groups were mobilized by the dominant elites and guided by the personal motivations of these leaders only to raise them against their landlords and make secure their own leadership position. The sharecroppers, agricultural labourers could not achieve political leadership and village headmanship. The lower and 
middle classes had formed alliance in terms of 'mutual understanding and accommodation of interests' (Dasgupta, 1984: A-146). In fact, the leftist leaders used 'class' as a currency to buy votes, which had nothing to do with lower-class emancipation. Since coming to power the left forces began to consolidate its rural power position by organizing and institutionalizing the peasantry and labourers, and also by politicizing the panchayats. ' $\ldots$ the very fact that the lower classes are mobilized for the first time against their landlords, will politicize the lower classes and eventually enable the creation of their own leadership from among their own class... the Bengali elite landed class-castes have organized the lower classes in Communist-influenced struggles against the dominant elite factions. It is clear that the Bengali village leadership is prepared to go further in mobilizing the lower classes against the dominant landed elite than elsewhere in India, ... This is justified as part of their multi-class alliance aimed at breaking the hegemony of the traditional elites, to enable the middle and lower classes to form a dominant alliance at the local level.' (Mallick, 1993: 132-33). The left forces headed by the CPI (M) adopted the policy of redistribution before growth and the strategy of 'mediated mobilization' conveniently coupled with two-pronged tactics, to prevent and to encourage, i.e. (a) preventing industrial stagnation through improvement of industrial relations, discouragement of labour unrest, etc.; and (b) encouraging rural employment, Operation Barga and the Food for Work Programme (Chatterjee, 1985: 19-21). By mobilizing the unsatisfied beneficiaries along electoralist path it has compromised the imperatives of democracy and capitalism and consolidated its position in running the government while sacrificing the revolutionary élan. ' $\ldots$ the allocation of resources which individuals prefer as citizens does not in general coincide with that at which they arrive via the market. Democracy in the political realm exacerbates this divergence by equalizing the right to influence the allocation of resources. Indeed, distributions of consumption caused by the market and those voted on by citizens must differ since democracy offers those who are poor, oppressed or otherwise miserable as a consequence of the initial distribution of endowments and opportunity to find redress via the state.' (Przeworski and Limongi, 1993: 53). Left forces headed by CPI (M) promote policies which are mildly progressive rather than radical. In some ways it has become the sort of party which Indira Gandhi said she wanted to build. The difference is that the CPI (M) has a strong party apparatus with collective leadership and a disciplined cadre. The left strategy revolved around the issue of redistribution before growth. The left 'strategy is to give something to everybody, not to subtract resources and powers from the rich and dominant classes and add them to the poor and oppressed classes. Otherwise the CPM, for example, would have used the powers it already has to heavily tax rural kulaks and transfer substantial benefits to the poor.' (Vanaik, 1990: 132). Kohli (1983) regards that 'the CPM's organizational arrangements allow it to penetrate the countryside without being captured by the propertied groups. In part because of the democratic-centralist nature of the party organization and in part because of the carefully reorganized local government, the CPM can now reach the lower peasantry without landlord mediation. This feature of the CPM distinguishes it from all other organised political alternatives in India. It allows the regime to channel some developmental resources directly to the rural poor, as well as to mobilize them for occasionally fulfilling reformist goals.' (Kohli, 1983: 806).

Gough (1981) finds that '... low-level class struggle by the middle peasants and the semi-proletarians went on in the form of thefts, rebellion against the ritual hierarchy, attempts to establish sexual equality with the upper class, and above all, attempts at economic and judicial emancipation... The landlords' powers to inflict this oppression rested on their ownership of private property and on the armed might of the state that upheld it. When necessary, these small village landlords used their ties - often kinship ties - to the police, lawyers, and a variety of government servants to uphold their dominance.' (Gough, 1981: 337). I am referring this with a view to highlighting the Left Front's policy of reformism rather than attempt to revolutionize the peasantry and change the Rural Power Structure. The rural productive system is dominated by Rural Power Structure. The left forces instead of capturing the power in a socio-economic way had produced Panchayat as a mechanism of electoral victory, where the rich and middle peasants captured the Panchayats with the support of the CPI (M). 'But to capture political power without preparing the socio-economic base for it may only promote economism and create delusions of progress.' (Gupta, 1972: 95). Therefore, with regard to the reforms in rural areas, the CPI (M)-led Left Front was then playing the rules of liberal democratic politics and playing the best in the form of relief to the people than the previous Congress (I) regime's profound stand on status quo. Hence, Franda points out Pran Chopra's conclusion and emotive asking: 'Should the CPM be able to demonstrate that it can rule effectively and bring about meaningful reform at the local level in West Bengal countryside?' (Franda, 1978: 143). CPI (M)'s primary goals are to redistribute productive assets and to decentralize political power. This has been attempted by Panchayats traditionally controlled by the rural vested interests, which has not been altered by the left forces. Left leaders explained that capitalist development in West Bengal was essential to increasing the purchasing power of the rural poor and providing capital accumulation for industrialization. It is passive revolution of capital, different from primitive accumulation of capital. In this respect Gramscian concept of 'passive revolution' is relevant. According to Gramsci (1971), in 'passive revolution' the new claimants to power necessarily opt for a path in which the demands of a new society are satisfied in reformist manners. In 'passive revolution' bourgeois hegemony is not accomplished in a classical way. It (passive revolution) is the 
process of political-ideological programme of the bourgeoisie, of alliances between the bourgeoisie and other dominant classes, and of mobilization under the leadership of this alliance of mass support from the subordinate classes. Post-colonial accumulation is combined with legitimization (Chatterjee, 1997). Planning and planned industrialization is a rational instrument for resolving conflicts. Irrational politics uses the instrument of planning for producing consent and legitimacy for capital's passive revolution. Habermas (1971) regards that 'state-regulated capitalism, which emerged from a reaction against the dangers to the system produced by open class antagonism, suspends class conflict. The system of advanced capitalism is so defined by a policy of securing the loyalty of the wage earning masses through rewards, that is, by avoiding conflict, that the conflict still built into the structure of society in virtue of the private mode of capital utilization is the very area of conflict which has the greatest probability of remaining latent. It recedes behind others, which, while conditioned by the mode of production, can no longer assume the form of class conflicts. This means not that class antagonisms have been abolished but that they have become latent. The political system has incorporated an interest - which transcends latent class boundaries - in preserving the compensatory distribution façade.' (Habermas, 1971: 107-109). Habermas formulated two types of rational actions, i.e. purposive rational action: growing capacity to control outer nature and development of productive forces and communicative rational action: expansion of realm of consensual action and overcoming of systematically distorted communication. Habermas (1976) contends that late organized capitalism are endangered from four crises: economic crisis as to the absence of 'requisite quantity' of produced consumable values; rationality crisis due to the absence of 'requisite quantity' of rational decisions; legitimation crisis because of the absence of the generation of 'requisite quantity' of 'generalized motivations'; and motivational crisis due to the absence of creation of 'requisite quantity' of 'action-motivating meaning'. The 'requisite quantity' essentially means the extent and quality of sub-systems' products like values, decisions, legitimizing actions and meanings (Habermas, 1976: 49). Habermas contends that the organized capitalism would evolve into a new world that will overcome class contradictions. This would evolve a universalistic morality embedded in a system of participatory democracy, providing the opportunity for discursive will. Gram Sabha or Gram Unnayan Parishad are examples of participatory democracy, communicative rationality and discursive will formation. Though in practice, this has not yet cropped up in the processes of grassroots democracy and Panchayati Raj systems in West Bengal. Habermas (1979) puts forward that 'democratization, greater popular participation and decentralization of the process of formation of the collective will are essential because the market + administration cannot satisfy a whole series of collective needs.' (Habermas, 1979: 81).

The left forces did not able to remove totally the shackles of feudalism as its leadership in West Bengal came from the middle class intellectuals. 'The only thing that was real about it was the quest for power - power which despite the revolutionary protestations of the party - was sought to be derived from the ballot box.' (Mohan, 1972: 86). The left parties only implemented parliamentary laws. Land reforms within the framework of legality and distribution of surplus lands were merely the tactics, but not strategies with long-term goals of socialist transformation; but appeasement of the land hunger of the as many people as possible. Lands above ceiling were distributed among the landless and the poor, hence the bargadars who traditionally cultivated lost their tenancy rights. '.. there was not enough land to distribute... It was that temporary whetting of their appetite for land would bring the landless labourers to the side of the party. The CPI (M) Kisan Sabha took the charge of distributing land on the ground that the party was the vanguard of the proletariat. Also, in order to maximize the number of party supporters, the workers (party workers) tried to distribute land to as many peasants as possible.' (Mitter, 1986: 598). The rural power structure based on concentration of land was then giving to a broad-based middle peasantry. Small and middle peasant proprietorship was not ruling the rural economy after the introduction of commercialism in agriculture and disaggregation of semi-feudalism: paying back the loans for consumption in grain from the legally stipulated shares, harvest-to-harvest survival through loans and hopeless grip of perpetual indebtedness. The CPI (M) led left incorporated the small and middle peasants into its organization than the lower ones (as it is found in the composition of its organizations), provided security of tenure to the share-croppers and sought to identify areas with concentration of sharecroppers; to politicize them through panchayats outmanoeuvring bureaucrats; and to register them illegally 'aiming at the limited goal of recording the tenancy right of the bargadars... The very fact that the Left Front did not try to cross the limit on the extent of tenancy reforms that was suggested by the Land Revenue Commission of British Bengal in 1940 and enacted by the Congress government in 1955, reveals that, unlike the first Communist government of Kerala, it had hardly any political will to go beyond what has somehow been accepted, at least in principle, by the existing political order.' (Khasnabis, 1986: 178-179). The main preoccupations of the Left Front government had been to keep the industrial workers on leash. The total ceasefire on the trade union front had been in operation. Collective bargaining and conciliation methods were taken as settlement of industrial disputes in West Bengal (Roy, 1977 and Ghosh, 1981). The left forces discouraged strike actions with the hope that it would vitiate new investment initiatives among the employers in the state and followed the necessary appeasement policy to the employers, while giving trade union rights to the 
industrial workers. Excessive reliance on conciliation and go slow approach had made the strike struggles ineffective. The number of strikes declined and number of lock-outs increased thereby (Roy, 1988: 1261). The left parties followed thereby the labour laws and had to operate the instruments of struggle, for example, strike, picketing and gherao within legal limits. Calcutta High Court in its remarkable judgement said that the 'recognized weapons in the hands of organized labour, namely strikes, picketing etc., if carried out within legal limits are portent weapons in the hands of labour... If it is thought by the trade unions that the labour laws are inadequate, or that they call for revisions or improvement, then what should be done is to agitate for their amendment or repeal. If employers do not carry the orders passed in industrial adjudications, there are procedures provided for their enforcement.' (Vaid, n.d.: 7-8). Strike actions were resorted to as the last weapon and inspite of labour militancy, the CITU, and the left leaders relied heavily on 'speedier labour conciliation, fewer work stoppages and stricter adherence to wage agreements' (Mitra, 1980: 25), and reduced the strike actions in industries to 'the minimum' (Report, 1977: 1). The Left Front government had inherited negative industrial growth and given priority to stimulating investment and curtailing working class militancy.

It is not market socialism as specified by Roemer (1992). It is social democracy as advocated by Kohli and Przeworski. There are two socialist aspects to the concept of market socialism. First, the government will have the power to intervene in the economy to direct the pattern and level of investment. People will thus exercise some collective control, through democratic politics, over the use of savings in society. In this sense there will be public control of the use of the economic surplus, a phrase with a socialist ring. The second socialist aspect of this economy is that the profits of firms will not go to a small fraction of the citizenry but will be divided, after taxes, more or less equally among all adult citizens; taking a form that Oskar Lange (1964) has called the social dividend. These are actualized through public sector undertakings and distribution of goods and services by the government. Thus, a citizen in this society will receive income from three sources: wage income, which will vary depending upon her skill and the amount of time she works, interest forthcoming from savings, which will also vary across households, and the social dividend, that will be, in principle, approximately equal across households. The social dividend will be a form of guaranteed income. This type of income is actualized through various development measures, especially the distribution of patta and barga lads for the deprived and landless people. Left forces' redistributive programmes are nevertheless impressive. But the left forces in West Bengal have totally dissociated from the socialist intents. A socialist government really based on socialism should have to carry out the socialist programmes at one stroke or to give up the programmes totally. Any hesitation, vacillation or a little bit or middle of the road policy would seriously damage the prestige of the government and provoke the economic collapse. Hence, the government must either promote private property and private enterprise in order to enable capitalist economy to function smoothly or with maximum speed it must go through resolutely with the socialist programmes. If the government has not the power to achieve comprehensive socialization, the socialists must form government with a successful 'labour plan'. 'But even a socialist government whose purposes are confined within the limits of such a labor plan needs boldness and decision in carrying out its program; otherwise it degenerates into a mere administrator of the existing capitalist society.' (Lange, 1964: 129).

\section{References:}

[1]. Alam, Javed. 1991. 'State and the Making of Communist Politics in India, 1947-57', Economic and Political Weekly (November).

[2]. Althusser, L. 1971. Lenin and Philosophy and other Essays (B. Brewster, Trans.) (New York: Monthly Review Books).

[3]. Bowles, Samuel and Gintis, Herbert. 1986. Democracy and Capitalism (New York: Basic Books).

[4]. Brass, Paul R. 1973. 'Political Parties of Radical Left in South Asian Politics' in Paul R. Brass and Marcus F. Franda (eds.), Radical Politics in South Asia (Massachussets: MIT Press).

[5]. Chatterjee, Partha. 1997. 'Development Planning and the Indian State' in Partha Chatterjee (ed.), State and Politics in India (New Delhi: Oxford University Press).

[6]. Chatterjee, Partha. 2004. The Politics of the Governed: Reflections on Popular Politics in Most of the World (New York: Columbia University Press).

[7]. Chatterjee, Rakhahari. 1985. 'Introduction' in Rakhahari Chatterjee (ed.), Politics in West Bengal (Calcutta: World Press Pvt. Ltd.).

[8]. Cohen, G.A. 1978. Karl Marx Theory of History (Princeton: Princeton University Press).

[9]. CPI(M), West Bengal State Committee. 1982. Bamfronter Nirbachani Ishtehar (in Bengali), Paschimbanga Bidhan Sabha Nirbachan (April 10).

[10]. CPI(M). 1986. Party Chitti (1) (in Bengali) (Calcutta: Paschimbanga Rajya Parishad).

[11]. CPI(M). 1986. Party Chitti (2) (in Bengali) (Calcutta: Paschimbanga Rajya Parishad).

[12]. CPI(M). 1986. Rajnaitik Sangathanik Report (in Bengali) (Calcutta: Paschimbanga Rajya Panchadash Sammelan).

[13]. CPI(M). 1988. Prastavali (in Bengali) (Calcutta: Paschimbanga Rajya Sorash Sammelan).

[14]. CPI(M). n.d. Kendriya Committeer Plename Grihita Sangathan Samparkita Prastav (in Bengali).

[15]. CPI. 1982. Dwadash Congresser Rajnaitik Prastav (in Bengali) (Calcutta: Paschimbanga Rajya Parishad).

[16]. CPI. 1982. Pargalochona (in Bengali) (Calcutta: Paschimbanga Rajya Parishad).

[17]. Dasgupta, Biplab. 1984. 'Agricultural Labour under Colonial, Semi-capitalist and Capitalist Conditions: A Case Study of West Bengal', Economic and Political Weekly (September 29).

[18]. Dattagupta, Sobhanlal. n.d. 'The Left in India and the Question of Political Power', Socialist Perspective (Vol. 15: Nos. 1-2).

[19]. Elster, Jon. 1985. Making sense of Marx ((UK: Cambridge University Press). 
[20]. Field, John Osgood and Franda, Marcus F. 1974. Electoral Politics in the Indian States: The Communist Parties of West Bengal (New Delhi: Manohar Books).

[21]. Fiske, John. 1992. 'British Cultural Studies and Television' in Allen, Robert C. (ed.). Channels of Discourse (London: Routledge).

[22]. Foucault, Michel. 2003. 'Society Must Be Defended', Lectures at the Coll' ege de France, 1975-1976 (New York: Macmillan).

[23]. Franda, Marcus F. 1978. India's Rural Development (Bloomington: Indiana University Press).

[24]. Ghosg, Krishnapada. 1981. Budget Speech (Calcutta: West Bengal Legislative Assembly).

[25]. Gough, Kathleen. 1981. Rural Society in South East Asia (Cambridge: Cambridge University Press).

[26]. Gramsci, Antonio. 1971. Selection from the Prison Notebooks (New York: International Publishers).

[27]. Gramsci, Antonio. 1975. The Prison Notebooks (New York: International Publishers).

[28]. Gupta, Ranjit Kumar. 1972. Agrarian West Bengal: Three Field Studies (Calcutta: Institute of Social Research and Applied Anthropology).

[29]. Habermas, J. 1971. Towards a Rational Society, trans. J. Shapiro (London: Heinemann).

[30]. Habermas, J. 1976. Legitimation Crisis, trans. T. McCarthy (London: Heinemann).

[31]. Habermas, J. 1979. 'Conservatism and Capitalist Crisis', New Left Review (No. 115: May-June).

[32]. Hall, Stuart. 1982. 'The Rediscovery of "Ideology”: Return of the Repressed in Media Studies' in Gurevitch et. al. (eds.), Culture, Society and the Media (London: Methuen).

[33]. Khasnabis, Ratan. 1986. 'More on West Bengal Tenancy Reforms', Economic and Political Weekly (Vol. XXI: No. 4).

[34]. Kohli, Atul. 1983. 'Parliamentary Communism and Agrarian Reform', Asian Survey (Vol. 23: No. 7).

[35]. Laclau, Ernesto. 1975. 'The Specificity of the Political: Around the Poulantzas-Miliband Debate', Economy and Society (Vol. 5: No. 1).

[36]. Lange, Oscar. 1964. On the Economic Theory of Socialism (New York: McGraw-Hill).

[37]. Mallick, Ross. 1993. Development Policy of a Communist Government (Cambridge: Cambridge University Press).

[38]. Mitra, Sumit. 1980. 'A Time for Restraint', India Today (June 16).

[39]. Mitter, Swasti. 1986. 'Peasant Movements in Sonarpur' in A.R. Desai (ed.), Agrarian Struggles in India after Independence (New Delhi: Oxford University Press).

[40]. Mohan, Ananda. 1972. 'Reviving the Sick Child' in Dhires Bhattacharya (ed.), Focus on West Bengal (Calcutta: Oxford Book and Stationary Company).

[41]. Nigam, Aditya. 1996. 'Hegemony and Counter-Hegemony: Understanding Indian Communism', Economic and Political Weekly (Vol. 31: No. 14).

[42]. Offe, Claus. 1984. Contradictions of the Welfare State (Massachussets: MIT Press).

[43]. Poulantzas, Nicos. 1969. 'The Problem of the Capitalist State', New Left Review (Vol. 58, November-December).

[44]. Poulantzas, Nicos. 1973. Political Power and Social Classes (London: New Left Books).

[45]. Poulantzas, Nicos. 1974. Fascism and Dictatorship (London: New Left Books).

[46]. Poulantzas, Nicos. 1975. Classes in Contemporary Capitalism (London: New Left Books).

[47]. Przeworski, Adam. 1977. 'Proletariat into a Class: The Process of Class Formation from Karl Kautsky's The Class Struggle to Recent Controversies', Politics and Society (Vol. 7), 343- 401.

[48]. Przeworski, Adam. 1980. 'Social Democracy as a Historical Phenomenon', New Left Review (Vol. 122).

[49]. Przeworski, Adam and Wallerstein, Michael. 1988. 'Structural Dependence of the State on Capital', American Political Science Review (Vol. 82).

[50]. Przeworski, Adam. 1990. The State and the Economy Under Capitalism (Switzerland: Harwood Academic Publishers).

[51]. Report. 1977. "'Strike should be the last resort, says Basu", The Statesman (July 2).

[52]. Retzlaff, Ralph. 1965. 'Revisionism and Dogmatism in the Communist Party of India' in Robert A. Scalapino (ed.), The Communist Revolution in Asia (New Jersey: Prentice-Hall).

[53]. Roemer, John E. 1985. "Rational Choice' Marxism: Some Issues of Method and Substance"” Economic and Political Weekly (Vol. 20: No. 34).

[54]. Roemer, John E. 1992. 'The Morality and Efficiency of Market Socialism', Ethics (Vol. 102: No. 3).

[55]. Roy, Ajit. 1977. 'Substituting Reform for Revolution', Economic and Political Weekly (December 31).

[56]. Roy, Biren. 1988. 'Appeasement of Employers Fails to Pay', Economic and Political Weekly (June 18).

[57]. Sen Gupta, Bhabani. 1981. 'Striving for Unity', India Today (January 1-15).

[58]. Vaid, K.N. n.d. Gheraos and Labour Unrest in West Bengal (New Delhi: Shri Ram Centre for Industrial Relations and Human Resources).

[59]. Vanaik, Achin. 1990. The Painful Transition (London: Verso).

[60]. Wright, Eric Olin. 1985. Classes (London: Verso). 


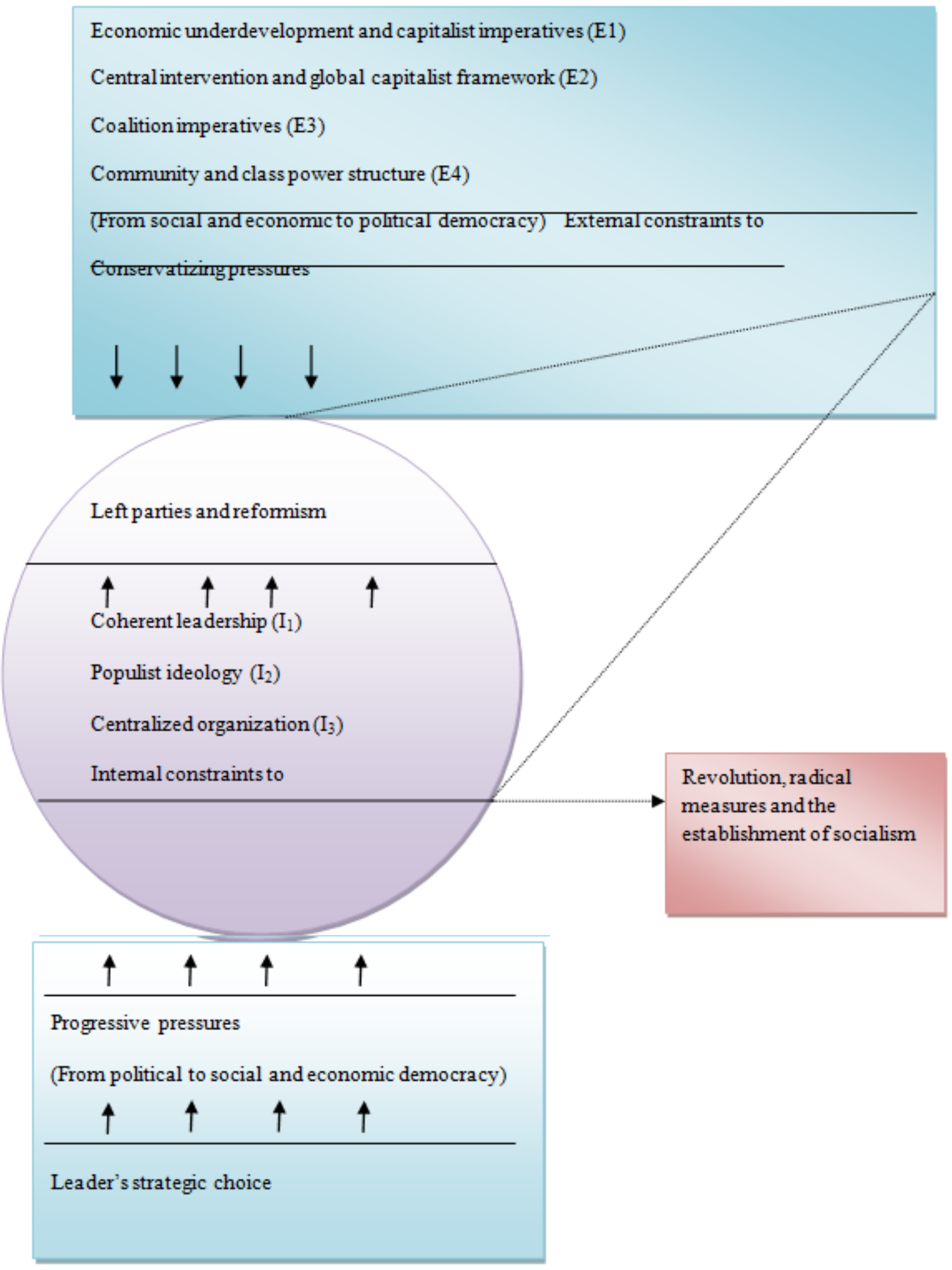

Fig. 1 